$\overline{\text { 総 } \text { 説 }}$

\title{
食品中に含まれる化学物質についての安全性評価
}

\section{三 森 国 敏*}

Safety Assessment on Chemical Substances Containing in Foods

Kunitoshi MitsumorI

(National Institute of Health Sciences: 1-18-1, Kamiyoga, Setagaya-ku,

Tokyo 158-8501, Japan)

はじめに

食品中には, 植物由来のものには農薬が, 動物由来の あのには動物用医薬品 (動物薬) が，また，それらの加 工品には食品添加物が, 微量ではあるが, 残留基準值以 下の濃度で含まれている．これらの化学物質は，植物や 水畜産動物の疾病予防・治療や成長促進, それらの加工 品の殺菌や防腐などのために使用されているものであ り，残留基準値以下であれば食品中にこれらが含まれて いてもヒトへの安全性は担保できるとの考えに基づき， 微量の残留が許容されている．この規制は我が国のみな らず，世界各国で既に実施されているものであり，国際 連合（国連）の食品規格委員会 (Codex Alimentarius Commission: CAC) では，各国の残留基準值の違いに よる食品の輸出入時における貿易摩擦を防止するため, コーデックス規格という世界共通の残留許容基準值を設 けている. 本総説では, これらの食品中に含まれる種々 の化学物質についてどのような安全性評価がなされた上 で, 許容基準值が設定されているかについて紹介する.

1. 一日摂取許容量 (ADI) の設定

国連の食糧農業機関 (FAO)/世界保健機構 (WHO) で は, 食品添加物, 污染物質, 動物薬の安全性評価を $\mathrm{FAO} / \mathrm{WHO}$ 合同食品添加物専門家委員会 $(\mathrm{JECFA})^{1)}$ が，農薬の安全性評価を FAO/WHO 合同残留農薬専門 家委員会 $(\mathrm{JMPR})^{2)}$ がそれぞれ行っている. ADI は, 現 時点で収集可能な毒性学的情報から考えた場合, ヒトが 生涯にわたって摄取しても有害作用が発現しないと考え られる化学物質の食品中残留の一日当たりの最大摂取量 と定義されている. ADI 設定に必要な毒性試験として は, 吸収・分布・代謝・排泄に関する試験, 単回及び反 復投与毒性試験, 生殖毒性試験, 変異原性試験, 発がん

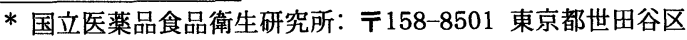
上用賀 1-18-1
性試験などが挙げられる：その他，抗生物質・抗菌剤な どの動物薬に対しては，これらの試験に加えて腸内細菌 についての微生物抑制試験が，また，アレルギーを誘発 する動物薬に対してはヒトでの臨床データなどあ要求さ れる.

\subsection{ADI 設定のための毒性試験法}

\subsection{1 反復投与毒性試験}

この試験法は 28 日から 3 か月の短期毒性試験と 1 か ら 2 年間の長期毒性試験からなり, 被験物質を所定の 期間ラット，マウスやイヌなどに反復投与する試験であ る（図 1). 試験期間中に体重, 死亡率, 摂餌・水量な どを测定し, 各投与終了時眼検査, 尿検查, 血液, 生化 学, 臟器重量, 病理学的検査などを実施する. その結果 から, 確実に毒性が発現する用量, 毒性が発現する最低 用量, 及び無毒性量 (NOAEL) が算定され, その中で最 あ低い NOAEL に安全係数が乗じられ ADI が算定さ れる.

\section{1 .2 二世代繁殖毒性試験}

ラットやゥサギを用いて交配, 着床, 器官形成, 胎児 期，授乳期など生殖過程全般に対する被験物質の影響を 検査する試験である（図 2)，通常，離乳した動物（F0

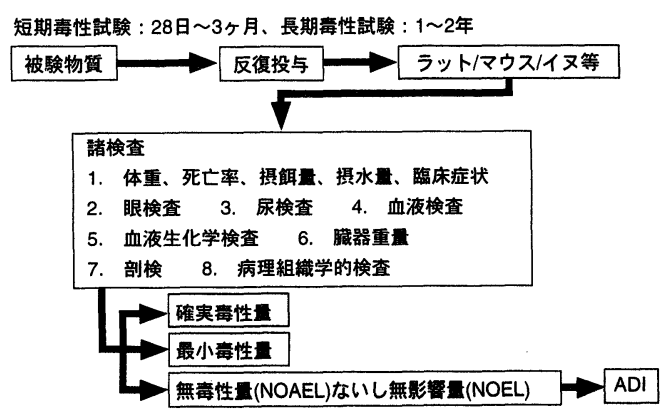

図 1. 反復投与毒性試験法の概要 


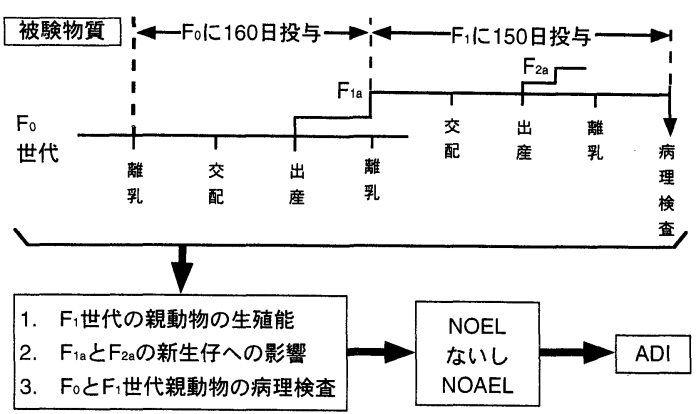

図 2. 二世代繁殖毒性試験法の概要

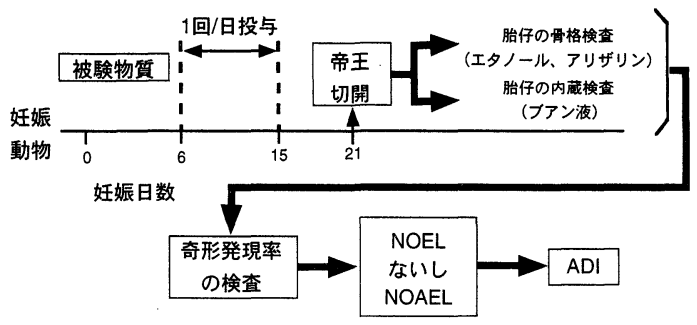

図 3. 催奇形性試験法の概要

世代）に 160 日間被験物質を投与し，その間に交配， 出産させる. 出生した次の世代 (F1世代) に離乳後 150 日間又被験物質を投与し, その間に交配, 出産さ せ, 次々世代 (F2 世代) を出生させる. 以上の投与試 験から, F1 世代の親動物の生殖能, F1 と F2 の新生児 への影響, F0 と F1世代親動物についての病理検査を 実施し，それらの成績から NOAELを求める。この NOAEL が最む低い場合はこの值から 1ADI が算定され ることもある。

\section{1 .3 催奇形性試験}

化学物質が先天異常の原因になるか否かを検査する試 験法である（図 3). 被験物質を妊娠ラットやウサギに 妊娠 6 から 15 日の間投与し妊娠 21 日目に帝王切開し, 胎児の骨格検查や内臓検查を行い，胎児の奇形発現が見 られない用量から NOAEL を求める.

\subsection{4 変異原性試験}

化学物質が遺伝子の構成成分の DNA を損傷するか否 かを検査する試験法である（図 4).この試験法には, in vitro と in vivo 試験法があり, in vitro 試験にはサ ルモネラなどを用いた野外株への復帰变異を検出する Ames 試験と哺乳動物培養細胞を用いた染色体異常を検 出する染色体異常試験がある. in vivo 試験には, 哺乳 動物の骨骾赤血球中の染色分体断片を調べる小核試験が ある。これらの試験で陽性結果が得られた場合には, こ の化学物質は遺伝毒性物質とみなされる。一方, 陰性の 場合は非遺伝毒性物質であり, ADI を算定でき得る.

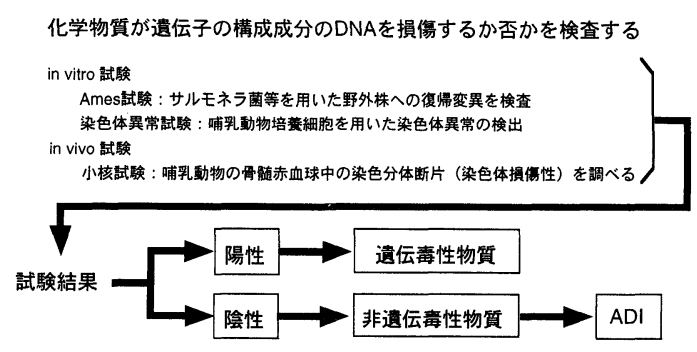

図 4. 変異原性試験法の概要

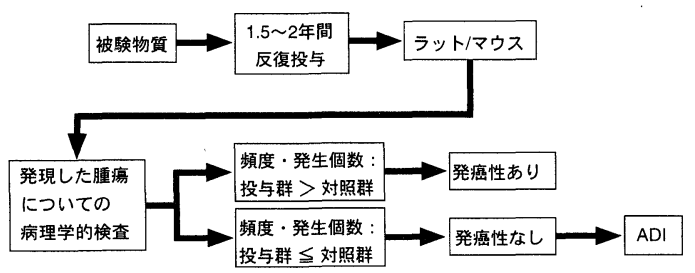

図 5. 発がん性試験法の概要

\subsection{5 発がん性試験}

ラットやマウスに被験物質を 1.5 から 2 年間反復投与 し，その発がん性の有無を検査する試験である（図 5). すべての動物について病理組織学的検查を実施し, 発現 した腫瘍の頻度や発生個数が対照群より投与群で高い場 合は発がん性ありと判定される. 一方, 低い場合は発が ん性なしと判定され，その他の毒性試験の NOAEL か ら ADI が算定される。

これらの毒性試験の結果次第で, ADI が設定できる 場合とできない場合がある.

\section{$1.2 \mathrm{ADI}$ が設定できない場合}

ADI が設定できない場合とは, 被験物質が変異原性 陽性かつ発がん性陽性の遺伝毒性発がん物質とみなされ た場合である。これは，生体の遺伝子に被験物質が直接 作用し, 遺伝子に突然変異を引き起こし, その結果とし て発がんや催奇形なら゙が誘発されるあのであり，このよ うな物質には閾值がないと考えられていることから， ヒ 卜にも同様な作用が起こる危険性があり, ADI は設定 されない.

\subsection{ADI が設定できる場合}

一方, ADI が設定できる場合とは, 変異原性が陰性 の非遺伝毒性物質の場合である，その場合には，各種の 毒性試験成績を総合的に評価して, 実験動物に対する NOAEL ないし無影響量 (NOEL) を求め, 安全係数で除 して,ADI が算出される (図 6). NOAEL/NOEL と は, 最も感受性の高い動物種において, 最屯感受性の高 い毒性指標において毒性徴候を生じない最大用量であ る.この用量は長期反復毒性試験から推定されることが 多い. 安全係数とは, 動物種とヒトとの感受性の差及び ヒト集団での感受性の個体差を考慮したもので，多くの 


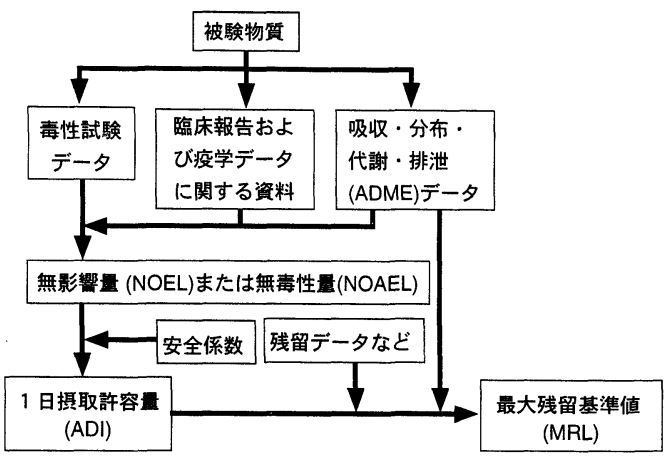

図 6. JECFA/JMPR における ADI/MRL 設定の ための決定プロセス

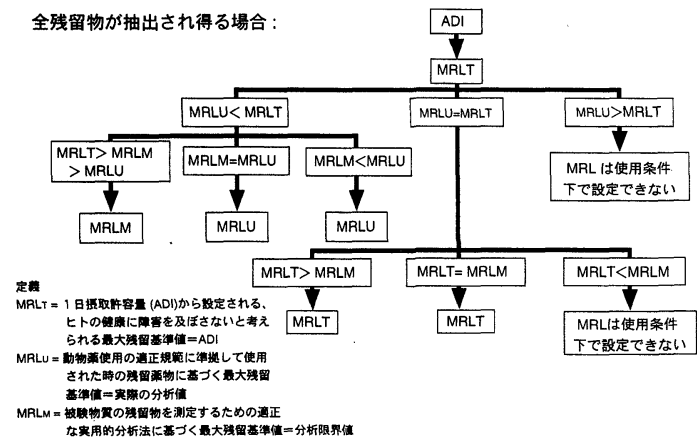

図 7. 残留動物薬についての JECFA の MRL 設定 方法

場合係数 100 が用いられる. 不十分な毒性デー夕を補 うために安全係数として $200,500,1,000,2,000$ などが 用いられている. 小さな数値は可逆性のある軽微な毒性 変化が見られた場合に, 大きな数值は不十分な毒性デー 夕を補うために用いられる. しかし, 抗生物質などの場 合には，ヒトの腸内細菌における 50\% 細菌抑制率から 算定した微生物学的 ADI の方が実験動物を用いた毒性 試験データからの毒性学的 ADI より著しく低いことか ら,このような抗菌製剤については, 微生物学的 $\mathrm{ADI}$ が設定されることが多い. 更に，アレルギーを誘発する 可能性のあるペニシリンのような楽剤については, 毒性 及び微生物学的 ADI を設定せず，ヒトでの臨床データ から直接一日当たりのアレルギー誘発の危険性がない摄 取量を算定する場合あある，発がん性があっても遺伝毒 性がないむのについては, ADI が算定される.これに ついては，第 4 項で後述する.

\section{2. 最大残留基準值 (MRL) の設定}

最大残留基準値 (MRL) は，植物由来食品中の農薬な いし畜水産食品中の動物薬における許容できる最大残留 濃度である。農薬についての MRL は, 適正農業規範 (GAP) に基づいて農薬を使用した場合に, 結果として

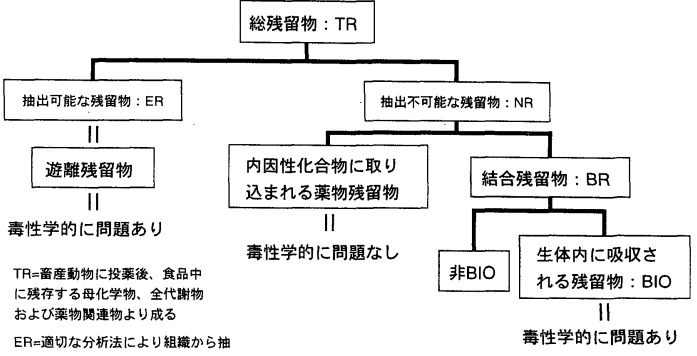

図 8. 食品中の動物薬の残留物

残留するレベルを超えない量として設定されている．動 物薬については，残留物がすべて抽出可能な場合は，適 正動物薬使用規範 (GVP) に従って使用された動物薬の 食品中残留濃度, ADI の濃度及び分析限界值を考慮し て MRL が設定される ${ }^{3), 4)}$. 一方，親化合物之同様の方 法では抽出が不可能な結合型残留物が多く含まれ，それ が親化合物よりも強い毒性を示す場合には，その結合型 残留物中で体内に吸収される可能性のある (bioavailable) な残留物の毒性が大きな問題となる，FAO/WHO では，このような場合，当該動物薬の毒性に対する結合 型残留物の関与を評価した上で，食品内残留值（抽出可 能な残留物と非抽出性の bioavailable な結合型残留物 の加算値）を算定している。

\section{1 残留物がすべて抽出可能な場合}

動物薬使用規範にしたがって使用された動物薬の残留 濃度が ADI の濃度よりあ低い場合は，MRL は，それ に応じて低く設定される．しかし，ある動物薬におい て，その使用条件下で通常の分析法を用いてあその残留 濃度が測定できない場合は，分析が可能なレベルにまで MRL は引き上げられる．ただし，毒性データの評価を 基にして設定された MRL を明らかに越えるような濃度 の MRL が勧告されることはない. 図 7 にその MRL 決 定プロセスを示した.

\section{2 結合型残留物が多い場合}

結合型残留物とは, 動物薬の親化合物ないしその代謝 物と細胞内の可溶性ないし不溶性高分子との共有結合に よって生じた残留物であり,これらは種々の抽出法や溶 解化方法によってもそれらの高分子化合物から抽出でき ないむのである，畜産物中における動物薬の総残留物 (total residue) は, 抽出性 (extractable) と非抽出性 (non-extractable) 残留物から成り, 非抽出性残留物は 更に楽物が生体内の構成成分に取り込まれる内因性化合 物之結合型残留物に分けられる（図 8). 毒性上問題之 なるのは, この結合型残留物であり, 特にその中の吸収 される可能性のある残留物 (bioavailable residue) は消 費者がそれを含有する食物を摂取した場合, 体内に吸収 される可能性が高い，この bioavailable な残留物が畜 


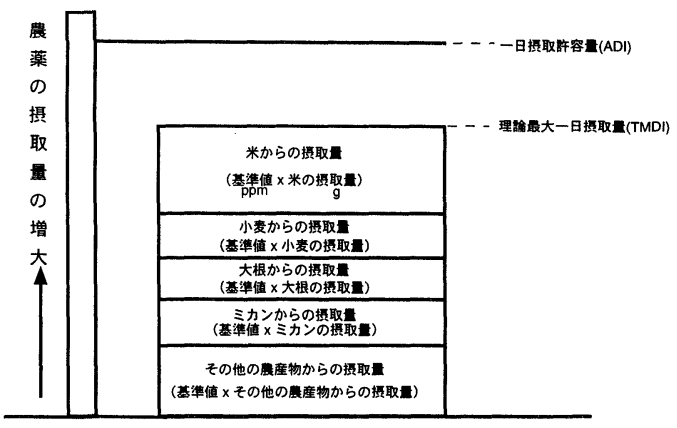

図 9. 残留農薬についての ADI と TMDI の関係

産食品中に多い場合には，この残留物についての毒性評 価が必要であり, また, このような化学物質の食品内残 留量は抽出性残留物之結合型残留物中の bioavailable な残留物濃度を加算することにより得られる. 特に, 結 合型残留物が ADI を設定した親化合物よりあ強い毒性 を示す場合では，その結合型残留物中で生体内に吸収さ れる可能性のある残留物の毒性が大きな問題となる.

$\mathrm{FAO} / \mathrm{WHO}$ では, このような場合, 当該動物薬の毒性 に対する結合型残留物の関与を評価し, 食品内残留値を 算定した上で, 既述の MRL 決定プロセスに基づき MRL を設定している31,4).

3. 理論的最大一日摄取量 (TMDI) の算定

設定された MRL が公衆衛生上受け入れられるか否か を決定するために，TMDI を用いた暴露評価が必要と なる. 農薬の場合, ある食品中の残留農薬の摄取量は, その食品中の残留レベルにその食品の消費量を乗じ，そ の残留物を含有するすべての食品由来の摂取量を合計し て残留農薬の食品に由来する全摄取量が算定される（図 9).この TMDI と ADI を比較し, TMDI が ADI より 少ない場合, これらの農薬や動物薬の食品中への使用が 許可される. 我が国では, この方法により,これらの薬 物の安全性確認を行っているところであるが, TMDI 方式による試算は, 実際の暴露量をあまりにあ過大に見 積もっているため, 残留農薬については, 基準設定にお ける安全性評価をより科学的なものとするため, より精 密な暴露量推定方式である推定一日摂取量 (EDI) 試算方 式を取り入れた指針が WHO から公表されている5). こ の新しい指針では, その試算に作物残留試験成績, 可食 部の残留農薬に関する試験成績, 加工調理の残留農薬へ の影響に関する試験成績などに基づく暴露量試算方式が 採用されている．更に，国民平均に加え，幼小児，妊 婦, 高齢者ごとの暴露評価む実施されることになり, ま た, 基準設定農作物以外の食品, 水, 空気などを介した 農楽の暴露も考慮されている. 我が国においても, 現 在, この新しい方式を導入するための検討が進められて 扔り, 近い将来この方式が導入されるようである.

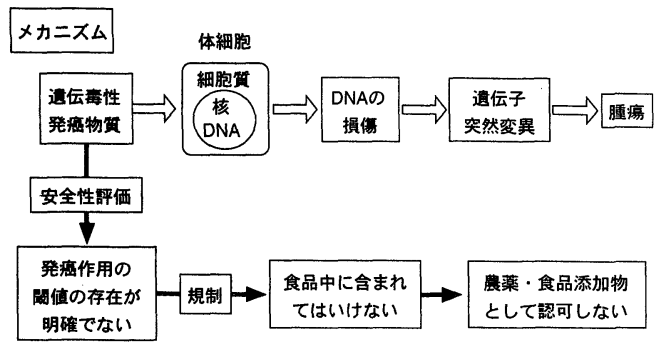

図 10．遺伝毒性発癌物質

以上のような暴露評価過程を経て食品中の化学物質に ついての安全性評価がなされており，ADIの設定に十 分な毒性データがない場合には暫定 ADI が, 安全性が 担保できない場合には ADI を設定しない規制が各国で とられている. 最近の科学の急速な進歩に伴い, 食生活 における安全性を更に高めるための各種試験法の改良や TMDI より精密な EDI 試算方式の導入などが検討され ており, 消費者への安全性を更に担保する努力が推し進 められている.

しかし，このような安全性評価が行われているにあか かわらず, 最近, 農薬の発がん性や内分泌攪乱物質の毒 性が世論をにぎわせている，以下に，その発がん性につ いての基本的考え方及び内分泌摫乱物質の毒性について の問題点について触れてみたい．

\section{4. 発がん物質についての基本的な考え方}

発がんのメカニズムには不明な点が多い. しかし, 動 物に長期間投与することによりがんの発生率を高め, あ るいは発がん時期を早めるような作用をるつ物質は, 大 別して, 標的細胞の遺伝子を障害する遺伝毒性発がん物 質 genotoxic carcinogen（一次発がん物質）と遺伝子 を障害しない非遺伝毒性発がん物質 non-genotoxic carcinogen の二つに, 更に後者は二次発がん物質と発 がんプロモーターの二つに分けることができるＷWHO の定義に従えば, 一次発がん物質, 二次発がん物質, 発 がんプロモーターのいずれあ発がん性があると判定され るが，その生物学的意義は全く異なる. すなわち，一次 発がん物質の作用は非可逆的であるが, 他の二つの作用 は本質的には可逆的と言うことである.したがって，こ れら三者は, 安全性の立場からみても，それぞれ別々の 評価の仕方で取り扱われるべきである。

遺伝毒性発がん物質とは, 既述のように, 被験物質も しくはその代謝物自身が標的細胞の遺伝子に直接作用し て突然変異を誘発後，がん化させるあので， $N$-ニトロ ソ化合物, 多環芳香族炭化水素, アルキル化剤などの強 力な発がん物質はすべて一次発がん物質に含まれる（図 10).これらについては, 発がん性に閾值がないことか ら, 食品中に含んではならないとの厳しい規制が課せら れている. 
非遺伝毒性発がん物質の中の二次発がん物質とは, 被 験物質の作用により生体のいずれかに細胞ががん化しや すい条件が作られるような場合で，ホルモン作用を有す る物質，生体の内分泌環境を乱すような物質及び被験物 質投与により生体内に産生される活性酸素のような物質 が標的細胞の遺伝子を二次的に障害する物質などがこれ に含まれる(図 11). 発がんプロモーターとは, 発がん 二段階説のイニシェーション及びプロモーションと呼ば れる二つの過程のうち, プロモーション作用を有する物 質の総称である.プロモーターには，「(1)プロモーター は少量の initiating agent の投与後に与えるとがんの 形成が促進され，腫瘍発生までの潜伏期間を短縮し，ま た腫瘍数の増加を来す. (2) プロモーターは, 本来それ 自体では発がん性を有しない. (3) プロモーターは initiating agent の投与前でなく，投与後に与えなければ その作用（プロモーター作用）を発揮しない. (4) プロ モーター作用には，プロモーターの長期間の投与が必要 であり, 通常, 投与初期の変化は可逆的である.」など の作用がある．これらには閾值が存在することから, 食 品中の暴露量を危険濃度以下に設定することにより

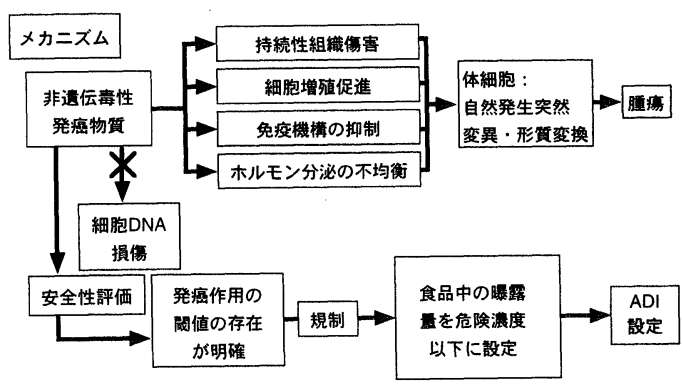

図 11. 非遺伝毒性発癌物質
ADI が算定可能である. したがって，このような非遺 伝毒性発がん物質は発がん性があっても ADI が算定さ れている.

\section{5. 内分泌攪乱物質の毒性についての問題点}

内分泌攪乱作用物質 (EDC) は，生体の恒常性，生殖 発生あるいは行動に関与する種々の生体内ホルモンの合 成, 貯蔵, 分泌, 体内輸送, 結合あるいはそのクリアラ ンスなどの諸過程を阻害する性質をもつ外来性の物質と 定義されており, 性ホルモンや甲状腺ホルモンなど種々 のホルモンの不均衡を誘発する化学物質すべてがこの範 疇に含まれる。この EDCは，最近頻繁に使用されてい る言葉であるが，種々の化学物質がこのような作用を有 することは，世界各国で現在勧告されている毒性試験ガ イドラインが策定される以前から既に知られている.し たがって, 医薬品, 農薬, 動物薬, 食品添加物や一般産 業化学物質として使用が認可されている物質の中にはこ の EDCに含まれるものが既に存在している.これらの $\mathrm{EDC}$ の内分泌臓器攑乱メカニズムは, 図 12 に示すよ うに，多岐にわたり，EDCの種類によりそのメカニズ ムはさまざまである，その中でも，エストロジェン類似 作用をむつ化学物質の微量投与により試験管内培養細胞 の増殖が促進されるとの研究結果が近年報告されたこと から，これらのEDCのうちエストロジェン作用を有す る化学物質がそのヒトへの健康影響上特に懸念される物 質として最近注目をあびている. その理由として，これ らの化学物質では，そのエストロジェン作用には閾値が ないとみなすべきであるとの議論がなされていること, また，これらの物質は生体内の性ホルモン結合グロブリ ンと結合しないため，エストロジェン作用の不活化がお こらないことから，胎児への EDCによる直接エストロ ジェン作用が懸念されるがその影響については十分明ら かにされていないことなどがあげられる.

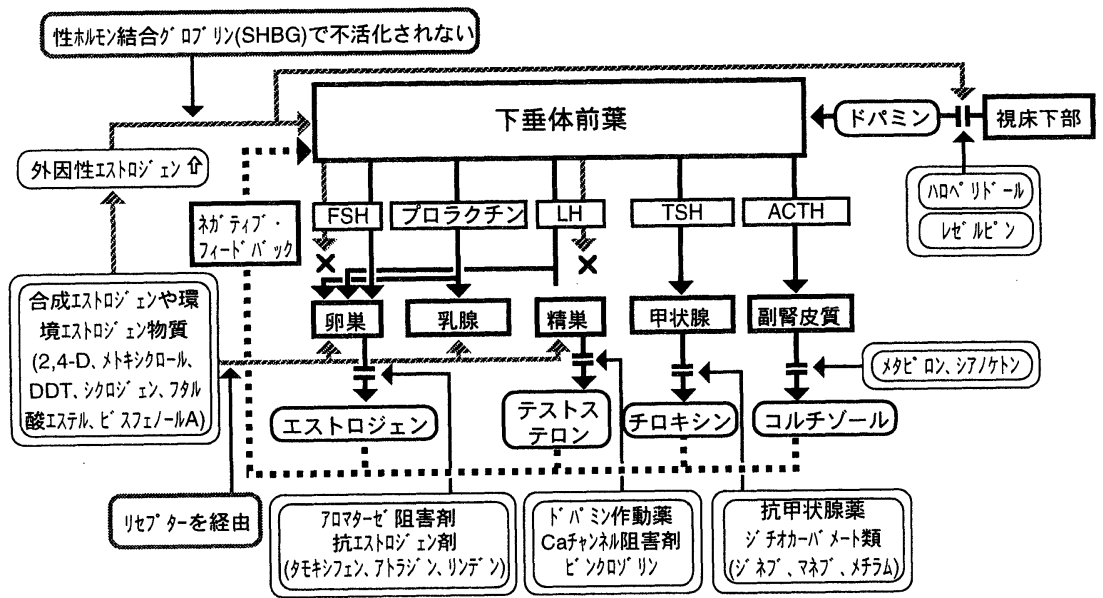

図 12. 内分泌擋乱物質とその障害部位 
ジェチルスチルベストロール (DES) を 0.01, 1, 2.5, 5, 10 ないし $100 \mu \mathrm{g} / \mathrm{kg}$ ラットに経胎盤投与すると, 100 $\mu \mathrm{g} / \mathrm{kg}$ 投与群の出生仔の雄に陰睪, 精巣の低形成, 精 子の質の低下, 精巣網の腺癌や間質細胞性腫瘍など, 七 トの DES 暴露例でみられる所見と同様の変化が誘発さ れるが, $10 \mu \mathrm{g} / \mathrm{kg}$ 以下の群ではこれらの変化は認めら れていない6). 同様の次世代の生殖機能への有害作用 は, メトキシクロール，ビンクロゾリンやミレックスな どの農薬やダイオキシンなどが投与された妊娠ラットや マウスの仔動物に発現することが報告されているが，こ れらの報告では実験に用いた最低用量までその有害作用 が認められており, その発現閾值がどのくらいなのかに ついてはさらなる実験が必要である.

一方, ビスフェノールA，フタル酸エステル，アラ クロールやケポンなどの弱いエストロジェン作用を有す る EDC では, 細胞培養などの in vitro 試験では微量投 与であエストロジェン作用が発現するが, 種々の in vivo 毒性試験では高用量投与しても実験動物の内分泌 や生殖器系にエストロジェン作用に起因する明らかな毒 性変化が発現することは少ない. しかし, 例外として, 妊娠マウスに $0.02 \mathrm{ppm}$ (慢性毒性試験における最小影 響量 $1,000 \mathrm{ppm}$ の 1/50,000）のビスフェノールAを 経胎盤投与して生まれた仔動物において性成熟後に精子 の一日産生量が半減したとの報告があり7), 微量の EDC 暴露により次世代の生殖能に影響を及ぼす可能性がある ことを示唆する実験成績も得られている.

以上の上うに, 現在の毒性試験では, 検查項目が内分 泌攪乱作用を検知するには必ずしも十分でないことか ら, 弱いエストロジェン作用を有するEDCを見逃して いる可能性が推察される。.また, エストロジェンないし 抗アンドロジェン作用を検出するための in vitro の試験 系は毒性試験ガイドラインとして未だ国際的に策定され ていないことから，これらの作用の有無について明確に されていない化学物質が未だたくさん残されていると思 われる. 現在, 農薬として登録されているものについて は次世代試験や発がん性試験を含む種々の毒性試験が実 施されていることから，これらを食品から摂取する消費 者に対してさしあたり安全性に何ら大きな問題はないと
思われる.しかし，EDCのヒトへの影響についての曖 昧さの原因となっている弱いエストロジェン作用を有す る EDC の微量投与による生体, 胎児及び次世代への影 響の有無を明確にするための研究の即時実施が強く望ま れており, 現在, 米国や我が国においてはこの種の毒性 試験が政府の予算で実施されている。

\section{文献}

1) WHO Environmental Health Criteria, No. 70: Principles for the safety assessment of food additives and contaminants in food. World Health Organization, Geneva, 1987.

2) WHO Environmental Health Criteria, No. 104: Principles for the toxicological assessment of pesticide residues in food. World Health Organization, Geneva, 1990.

3) WHO Technical Report Series No. 788: Evaluation of certain veterinary drug residues in food. Thirtyfourth report of JECFA. World Health Organization, Geneva, 1989.

4) WHO Technical Report Series No. 799: Evaluation of certain veterinary drug residues in food. Thirtysixth report of JECFA. World Health Organization, Geneva, 1990.

5) FAO/WHO: Food consumption and exposure assessment to chemicals in food. Report of Joint FAO/ WHO Consultation. 10-14 February 1997. Geneva, WHO/FNU/FOS, 1997.

6) McLachlan, J. A.: Rodent models for perinatal exposure to diethylstilbestrol and their relation to human disease in the male, cited in: Herbst, A. L. and Bern, H. A. eds., Developmental Effects of Diethylstilbestrol in Pregnancy. Thieme-Stratton, New York, 1981, p. 148.

7) Vom Saal, F. S., Cooke, P., Buchanan, D. L., Palanza, P., Thayer, K. A., Nagel, S. C., Parmigiani, S., Welshons, W.: A physiologically based approach to the study of bisphenol A and other estrogenic chemicals on the size of reproductive organs, daily sperm production, and behavior. Toxicol. Indust. Hlth. 14, 239 260 (1998). 